\title{
Non-specific humoural immunity response in latent and tertiary syphilis
}

\author{
Z. HRNČÍR, Z. KRAUS, AND M. TICHÝ \\ Second Department of Medicine and Department of Dermatovenereology, Faculty of Medicine, Charles \\ University, Hradec Kralové, Czechoslovakia
}

Chronic infectious diseases are one of the frequent causes of long-term antigenic stimulation. This is suggested both by the indices of humoural immune response and by changes in the delayed type of hypersensitivity. The immune responses of both types may include two kinds of changes: Those relatively specific for the given disease and those nosologically non-specific or typical of a different disease or group of diseases.

The various immunological changes are exemplified in patients with syphilis. These include the relatively specific positivity in a battery of serological tests, but recent observations have revealed that these responses are only a part of a broader spectrum of abnormalities demonstrating the extent of deviations in the activity of the immune apparatus in this disease. Among the non-specific changes in the delayed type of immune response, is the lower percentage of phytohaemagglutinin-blast-transformed lymphocytes in primary and secondary syphilis described by Levene, Turk, Wright, and Grimble (1969). Among the indices of changed humoural immune response, dysimmunoglobinaemia with increase of IgG and IgM was described by Delhanty and Catterall (1969). A few studies with different conclusions have been concerned with antibodies of the rheumatoid-factor type (Bloomfield, 1960; Pinto, 1960; Peltier and Christian, 1959; Mustakallio, Lassus, and Wager, 1967; Lassus 1969; Hrnčír, 1970).

The object of the present study was to determine the extent of non-specific changes in humoural immunity by means of a set of examinations that, up to the present, have been carried out only sporadically or with varying results in cases of syphilis, or have not been carried out at all with respect to some indices. Patients with latent and late symptomatic syphilis were examined, because the authors consider them to be the most suitable forms for studying the permanent character of humoural immune responses.

Received for publication July 15, 1971

\section{Material}

The series tested consisted of 53 patients with syphilis (22 males and 31 females). Their average age was 58 years (range 20 to 80 ). The basic disease was demonstrated by laboratory or clinical findings (and by laboratory tests only in cases of latent disease). Serological tests included the RPR and VDRL reactions using cardiolipin antigen, the test with Kahn's antigen, and the Kolmer complementfixation test with cardiolipin. In cases with anomalous test results, the Treponema pallidum immobilization test (TPI) was carried out. Latent syphilis was demonstrated in 42 cases, and late neurosyphilis or cardiovascular disease in eleven cases. All patients were under regular clinical and laboratory surveillance. In no case was there a coincidental connective tissue disease or chronic hepatic disease, as shown by clinical evidence or by standard laboratory examinations, i.e. tests for bile pigment in the urine, and hyper-bilirubinaemia estimates of serum transaminases, and flocculation tests. The control group, drawn from blood donors, consisted of 180 clinically healthy subjects matched by age and sex. For haemagglutination tests and tests for antinuclear antibodies there were 120 subjects. Before blood was drawn for laboratory analyses the subjects underwent clinical examination and laboratory tests (i.e. erythrocyte sedimentation rate, blood count, chemical and microscopical urine tests, SGOT and SGPT).

\section{Methods}

Sera were stored at $-20^{\circ} \mathrm{C}$. until tested. Serological studies included:

(1) Total protein determination using the biuret reagent; the coefficient of variation (c.v.) was $1 \cdot 14$ per cent.

(2) Paper electrophoresis using veronal-acetate buffer, pH 9.0, 0.06 u., Whatman No. 1 paper, $90 \mathrm{~V}, 16 \mathrm{hrs,}$ densitometer ERI 65, Zeiss, Jena; c.v. for the components of the protein spectrum were as follows: albumin 2.7 per cent., alpha $a_{1}$ globulin 3.9 per cent., alpha $a_{2}$ globulin 3.7 per cent., beta globulin 3.4 per cent., and gamma globulin $2 \cdot 1$ per cent.

(3) Quantitative determination of $A, G$, and $M$ immunoglobulins by the radial immunodiffusion method of Mancini, Carbonata, and Heremans (1965), using commercial sets IDP (products of the Institute of Sera and Vaccines 'SEVAC', Prague). The standards of IgG, IgA, 
and $\operatorname{IgM}$ used in these sets were verified in the Reference Centre for Immunoglobulins in Springfield and registered at the International Reference Centre for Immunoglobulins in Lausanne. The values of c.v. were as follows: 1.4 per cent. for IgG, 2.7 per cent. for IgA, and 6.0 per cent. for IgM;

(4) Quantitative determination of serum SH-groups level using the spectro-photometric method of Ellman (1959): the c.v. was $1 \cdot 1$ per cent.;

(5) Rheumatoid factor activity (RF) was tested by the tube latex-fixation test (Singer and Plotz, 1956) and the sheep red cell agglutination test (Ball, 1950). A titre of $1: 160$ or higher in the latex-fixation test and a titre of 1:64 or higher in the sheep red cell agglutination test were considered positive findings;

(6) Antinuclear antibodies (ANA) were detected by an indirect cytoimmunofluorescent technique described by Alexander, Bremner, and Duthie (1960) using a rabbit antihuman gammaglobulin serum, conjugated with fluorescein-isothiocyanate (RAHu/FITC SEVAC). When nuclear fluorescence was detected in an undiluted serum specimen, the specimen was diluted with saline to obtain a semiquantitative result by finding the maximum titre with positive nuclear fluorescence (Ritchie, 1967). In both tests used for detection of RF and of ANA, appropriate positive control sera of known titre and a proved negative sera were always examined. To test the reproducibility of the methods, the same sample of serum was examined ten times. Identical values were obtained each time in the latex-fixation test and in the haemagglutination test with sheep erythrocytes. In the cytoimmunofluorescent test, the values were identical eight times, but in two cases the value was one degree lower in the titration scale. Normal human peripheral blood smears were obtained from ten donors.

Statistical evaluation of the results was carried out by computer with the non-paired t-test (for IgA, IgG, and IgM values log t-test) and non-paired Wilcoxon test: for analysis of RF and ANA results the $\chi^{2}$ test was used.

\section{Results}

In the patients with syphilis, the average total serum protein level was $8.09 \mathrm{~g} .100 \mathrm{ml}$. (95 per cent. range $7 \cdot 81$ to 8.38 ) and was significantly higher than in the control group $(P=0.01$ to 0.001 ). The average values of protein spectrum components in $\mathrm{g} . / 100 \mathrm{ml}$. by paper electrophoresis were as follows:

Albumin 3.70 (95 per cent. range 3.56 to 3.85).

Alpha $_{1}$ globulin 0.40 (95 per cent. range 0.37 to 0.43).

Alpha $_{2}$ globulin 0.93 (95 per cent. range 0.88 to 0.97).

Beta globulin 1.11 (95 per cent. range 1.06 to 1.17 ).

Gamma globulin 1.93 (95 per cent. range 1.82 to 2.04).

Significantly higher values $(P=0.05$ to 0.001$)$ than in the controls were found in all components of the electrophoretic pattern (Fig. 1).

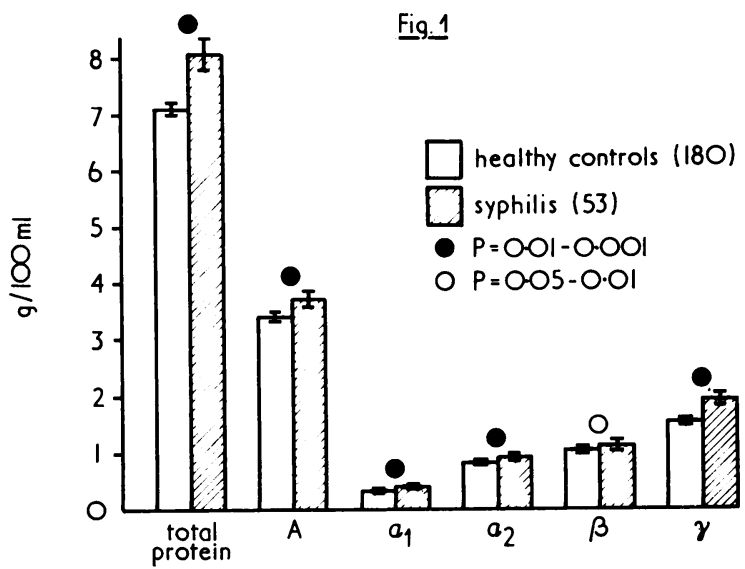

FIG. 1 Total serum protein and electrophoretic fractions in syphilitic patients and controls

The average serum concentrations of immunoglobulins expressed in $\mathrm{mg} . / 100 \mathrm{ml}$. (Fig. 2) were as follows:

IgA 436 (95 per cent. range 389 to 484 ).

IgG 1,720 (95 per cent. range 1,636 to 1,805 ).

IgM 163 (95 per cent. range 135 to 190 ).

The values of IgG and IgM in patients were significantly higher than in controls $(P=0.01$ to 0.001 ). The average level of $\mathrm{SH}$ groups in the serum expressed in $\mathrm{mM} / 1$. was 0.43 (95 per cent. range 0.40

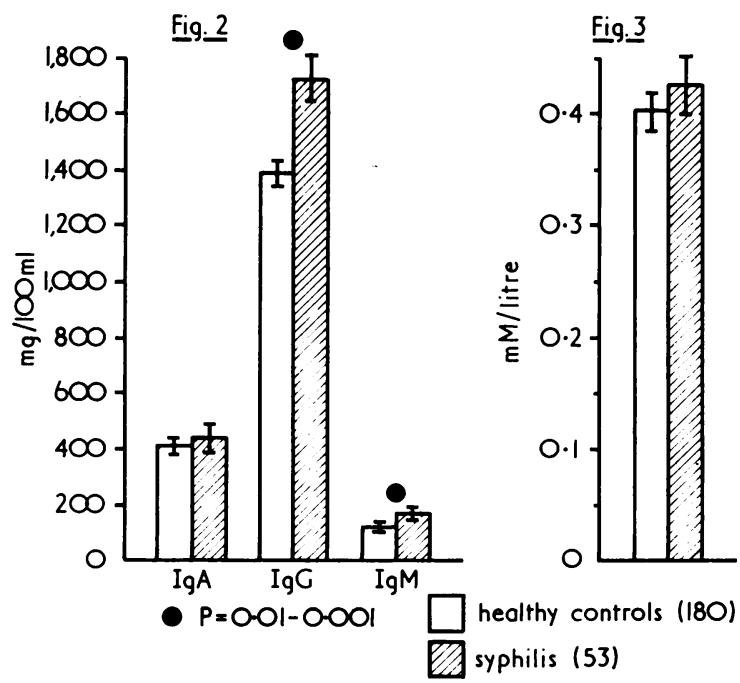

FI G. 2 Immunoglobulins $A, G$, and $M$ in syphilitic patients and controls

FIG. 3 Serum levels of $S H$ groups in syphilitic patients and controls 
to 0.45$)$ : this value was not significantly different from that in the control group (Fig. 3, see p. 109).

Statistical evaluation of all data in the series showed no significant differences in any of the test results between patients with latent infection and those with late symptomatic syphilis. Latex tests for RF were positive at a significant titre in three patients with syphilis (5.7 per cent.) and in 27 in the control group (15.0) (Table I). This was not statistically significant $(P=>0.05)$.

TABLE I Latex-fixation test in syphilitics and controls

\begin{tabular}{|c|c|c|c|c|}
\hline \multirow{2}{*}{$\begin{array}{l}\text { Latex-fixation } \\
\text { test } \\
\text { (Reciprocal titre) }\end{array}$} & \multicolumn{2}{|c|}{ Controls } & \multicolumn{2}{|c|}{ Syphilitics } \\
\hline & No. & Per cent. & No. & Per cent. \\
\hline 0 & 97 & 53.9 & 39 & $73 \cdot 5$ \\
\hline 20 & 20 & $11 \cdot 1$ & 6 & $11 \cdot 3$ \\
\hline 40 & 18 & 10 & 2 & 3.7 \\
\hline 80 & 18 & 10 & 3 & $5 \cdot 7$ \\
\hline 160 & 20 & $11 \cdot 1$ & 3 & $5 \cdot 7$ \\
\hline 320 & 2 & $1 \cdot 1$ & & \\
\hline 640 & 2 & $1 \cdot 1$ & & \\
\hline 1,280 & 0 & 0 & & \\
\hline 2,560 & 2 & $1 \cdot 1$ & & \\
\hline 5,120 & 1 & 0.5 & & \\
\hline
\end{tabular}

Similar results for rheumatoid factor (Table II) were obtained with the sensitized sheep erythrocyte agglutimation test (Ball, 1950): a titre of 1:64 and higher was found in five patients with syphilis $(9 \cdot 5$ per cent.) and in seventeen subjects from the control group (i.e. 14.2 per cent.): These differences were not significant $(P=>0.05)$.

TABLE II Haemagglutination test in syphilitics and controls

\begin{tabular}{|c|c|c|c|c|}
\hline \multirow{2}{*}{$\begin{array}{l}\text { Sheep-cell } \\
\text { agglutination test } \\
\text { (Reciprocal titre) }\end{array}$} & \multicolumn{2}{|c|}{ Controls } & \multicolumn{2}{|c|}{ Syphilitics } \\
\hline & No. & Per cent. & No. & Per cent. \\
\hline $\begin{array}{r}0 \\
4 \\
8 \\
16 \\
32\end{array}$ & $\begin{array}{l}43 \\
16 \\
12 \\
14 \\
18\end{array}$ & $\begin{array}{l}35 \cdot 8 \\
13 \cdot 3 \\
10 \\
11 \cdot 7 \\
15\end{array}$ & $\begin{array}{r}17 \\
5 \\
10 \\
7 \\
9\end{array}$ & $\begin{array}{c}32 \\
9 \cdot 4 \\
18 \cdot 8 \\
13 \cdot 2 \\
17 \cdot 1\end{array}$ \\
\hline $\begin{array}{r}64 \\
128 \\
256\end{array}$ & $\begin{array}{l}8 \\
5 \\
4\end{array}$ & $\begin{array}{l}6 \cdot 7 \\
4 \cdot 2 \\
3 \cdot 3\end{array}$ & $\begin{array}{l}3 \\
1 \\
1\end{array}$ & $\begin{array}{l}5 \cdot 7 \\
1.9 \\
1.9\end{array}$ \\
\hline
\end{tabular}

The results of tests for antinuclear antibody expressed in increasing serum titres are summarized in Table III; no statistically significant differences were found between the groups compared $(P=>0.05)$.

\section{Discussion}

Dysproteinaemia accompanied by increase of the globulin fraction of the serum, particularly of the
TABLE III Antinuclear antibodies in syphilitics and controls

\begin{tabular}{|c|c|c|c|c|}
\hline \multirow{2}{*}{$\begin{array}{l}\text { Antinuclear } \\
\text { antibodies } \\
\text { (Reciprocal titre) }\end{array}$} & \multicolumn{2}{|c|}{ Controls } & \multicolumn{2}{|c|}{ Syphilitics } \\
\hline & No. & Per cent. & No. & Per cent. \\
\hline$<4$ & 53 & $44 \cdot 2$ & 11 & $20 \cdot 8$ \\
\hline 4 & 35 & $29 \cdot 2$ & 13 & $24 \cdot 4$ \\
\hline 8 & 9 & $7 \cdot 5$ & 11 & $20 \cdot 8$ \\
\hline 16 & 13 & $10 \cdot 8$ & 11 & $20 \cdot 8$ \\
\hline 32 & 3 & $2 \cdot 5$ & 5 & $9 \cdot 4$ \\
\hline 64 & 6 & 5 & 1 & 1.9 \\
\hline 128 & & & 1 & 1.9 \\
\hline 256 & 1 & 0.8 & & \\
\hline
\end{tabular}

gamma globulins in the electrophoretic pattern, is a typical laboratory finding in chronic infectious diseases. This was also confirmed by the findings in the series of syphilitic patients. The absolute values of all fractions of serum proteins separated by electrophoresis were raised to a highly significant degree $(P=0.01$ to 0.001$)$, with the exception of beta globulin, as compared with the levels in control subjects of corresponding age. These changes were the cause of a highly significant increase in the total proteins $(P=0.01$ to 0.001$)$. The expression of the results in absolute values of the individual fractions of serum proteins is indispensable because with even changes in the whole protein spectrum the proportion of the fractions does not change much, but values expressed in percentages may give a misleading impression of a normal pattern of proteins. The practical value of this observation is that it demonstrates the possibility of latent syphilis as a cause of clinically obscure hyperproteinaemia, particularly one caused by an increase in all the fractions in the electrophoretic pattern (Fig. 1).

The pattern of immunoglobulins in cases of syphilis has been tested only sporadically. Onisk (1965) used the immunoelectrophoretic method, which yields a largely qualitative pattern. Delhanty and Catterall (1969), who carried out a quantitative analysis of the main classes of immunoglobulins in the sera of 55 syphilitic patients, oberved a significant increase in IgG and IgM in cases of primary, secondary, and latent syphilis as compared with a control series of 32 normal males. We found a highly significant increase in IgG and IgM (P $=0.01$ to 0.001 ) in our series of patients with latent and late symptomatic syphilis as compared with a series of 180 clinically healthy subject of corresponding age. No significant difference was observed in the circulating IgA levels. We consider the observation of average ages in each series to be important because we have previously demonstrated a significantly higher level of circulating IgG in blood donors aged 40-49 and 50-59 years compared with those aged 20-29 years (Hrnčíř, Tichý, Matěja, and Mazák, 1971). 
The increased IgG and IgM levels in patients with syphilis is understandable if we consider that antilipoidal syphilitic antibodies are located in these immunoglobulin classes; on ultra centrifugation they exhibit both the coefficients 7S and 19S. Aho (1967, 1968) found antibodies with the sedimentation coefficient $7 \mathrm{~S}$ mainly in primary and early latent syphilis, and those with $19 \mathrm{~S}$ in late syphilis. In our series the increase in IgG and IgM in latent and late symptomatic cases is indirect evidence of the presence of syphilitic antilipoidal antibodies of both types.

Dysimmunoglobulinaemia with increased IgG and IgM has also been observed in other specific and non-specific infections, such as lepromatous leprosy and chronic bronchitis (Bullock, Ho, and Chen, 1970; Falk, Siskind, and Smith, 1970). There is obviously a non-specific component of the 'immunological syndrome' in long-term antigenic stimulation, it may be a component of the immune response to the antigens of the aetiological agent persisting in the organism, or may be of autoimmune character. In the latter case, it is induced by the agent of the disease in an indirect manner through the antigenic determinants newly developed by damage to tissue. This mechanism is suggested by the observation of autoantibodies to both infected and normal renal tissue in chronic experimental pyelonephritis (Miller, Smith, Lehmann, and Sanford, 1970).

The level of SH groups in the serum of syphilitic patients has not previously been examined. A decrease was originally observed in Waldenstrom's macroglobulinaemia and in systemic connective tissue diseases (Lorber, Pearson, Meredith, and Gantz-Mandell, 1964). It was to be expected that in our cases the findings did not differ significantly from those in the controls.

Whereas the presence of RF is typical of rheumatoid arthritis, it can also be found in a few cases of non-rheumatic disease and in clinically healthy subjects. Among the non-rheumatic conditions, chronic liver disease and disorders accompanied by paraproteinaemia are the most frequent (Hrnčír, 1970); all these possibilities were excluded in the series reported above. The frequency of positive tests for RF at diagnostically significant titres with both the latex-fixation test (Table I) and the haemoglutination test (Table II) was lower than in the age-matched controls. Our earlier findings (Hrnčír, 1970) in 100 syphilitic patients have thus been confirmed. In that series, both tests were positive in three cases and the latex-fixation test only was positive in seven. Clinical and laboratory examinations subsequently showed that concidence with rheumatoid arthritis had occurred in two cases, while four other patients suffered from chronic liver disease.

After the elimination of observations explained by these cases, the frequency of RF in the syphilitic patients was no higher than in the control group. A low incidence of RF in cases of syphilis was also reported by Bloomfield (1960), who found that the latex-fixation test was positive in a titre of $1: 160$ or more in only seven cases in a series of 232 patients. Other authors have reported a more frequent occurrence of RF in syphilitic sera (Peltier, 1959; Pinto, 1960; Mustakallio and others, 1967; Lassus, 1969), but their examinations were limited to the latexfixation slide test which is only a screening procedure. When the haemagglutination test was used at the same time, the frequency of positive findings was low. Lassus (1969) found only one positive result in a series of 152 patients. The low frequency of RF in syphilitic sera differs from the findings in a number of other chronic infectious diseases, in which RF autoantibodies have been repeatedly observed in a fairly high percentage of cases. This applies particularly to active pulmonary tuberculosis (Singer, Plotz, Peralta, and Lyons, 1962), subacute bacterial endocarditis (Williams and Kunkel, 1962); Messner, Laxdal, Quie, and Williams, 1968), leprosy (Cathcart, Williams, Ross, and Calkins, 1961), and certain parasitic tropical diseases (Houba and Allison, 1966).

ANA have frequently been found in the sera of patients with biological false positive reactions (Berglund and Carlsson, 1966). Norins, Logan, and Lantz (1970) described apparent false-positive reactions (the RPR, VDRL slide, and FTA-ABS tests) associated with the presence of ANA in hybrid mice. We therefore consider it significant that the values of the ANA titres in syphilitic cases did not differ from those in the controls. This may contribute to the differentiation of biological false positive reactions. Our observations are also of value because not even a large series of immunochemical tests (Aho, 1968) enabled antilipoidal antibodies in syphilitic sera to be clearly distinguished from those in subjects giving chronic false positive reactions for syphilis.

The occurrence of hyperproteinaemia with hypergammaglobulinaemia and an increase of $\mathrm{IgG}$ and IgM in the sera of patients with latent and late symptomatic syphilis shows that the aetiological agent is the source of long-term antigenic stimulation with a humoural-type immune response. The low incidence of RF and ANA autoantibodies suggests the presence of an immune response to the antigens of the aetiological agent rather than of an autoimmune antigenic response in damaged tissues. 


\section{Summary}

Non-specific signs of humoural immunity were studied in sera from 53 patients with latent and late symptomatic syphilis and from a control group of 180 clinically healthy subjects of the same average age. In the syphilitic sera the values for total serum proteins, protein fractions in the electrophoretic pattern, and immunoglobulins $G$ and $M$ were increased to a highly significantly degree. The differences in SH groups were not significant. Autoantibodies of the rheumatoid factor type, and antinuclear antibodies were not found more frequently in the syphilitic sera than in the controls.

On the basis of these findings, it is concluded that non-specific changes in humoural immunity suggestive of persistent antigenic stimulation can be demonstrated in both late symptomatic and latent syphilis. The changes appear to be due to an immune response to the antigens of the aetiological agent of the disease rather than to an autoimmune mechanism induced by antigenic determinents newly developed in damaged tissues.

\section{References}

Aно, K. (1967) Brit. F. vener. Dis., 43, 259

- (1968) Ibid., 44, 49

Alexander, W. R. M., Bremner, J. M., and Duthie, J. J. R. (1960) Ann. rheum. Dis., 19, 338

BaLl, J. (1950) Lancet, 2, 520

Berglund, S., and Carlsson, M. (1966) Acta med. scand., 180,407

Bloomfield, N. (1960) f. Lab. clin. Med., 55, 73

Bullock, W. E., MIN-Fu Ho, and MeI-JAN CheN (1970) Ibid., 75, 863

Cathcart, E. S., Williams, R. C., Ross, H., and Calkins, E. (1961) Amer. F. Med., 31, 758

Delhanty, J. J., and Catterall, R. D. (1969) Lancet, 2, 1099

Ellman, G. L. (1959) Arch. Biochem., 82, 70

FALK, G. A., Siskind, G. W., and SMITH, J. P. (1970) f. Immunol., 105, 1559

HoubA, V., and Allison, A. C. (1966) Lancet, 1, 848

HRNČf̌́, Z. (1970) 'Revmatoidní faktor u nerevmatiko'. Avicenum, Prague

—, TichÝ, M. Matéja, F., and MazÁk, J. (1971) Cas. Lék. čes., 110, 837

Lassus, A. (1969) Int. Arch. Allerg., 36, 515

LEVENE, G. M., TURK, J. L., WRIGHT, D. J. M., and GrIMBLE, A. G. S. (1969) Lancet, 2, 246
Lorber, A., Pearson, C. M., Meredith, W. L., and GantZ-Mandell, L. E. (1964) Ann. intern. Med., 61, 423

Mancini, G., Carbonara, A. O., and Heremans, J. F. (1965) Immuno-chemistry, 2, 235

Messner, R. P., LAXDal, T., Quie, P. G., and Williams, R. C., Jr. (1968) Ann. intern. Med., 68, 746

MilleR, T. E., Smith, J. W., LehmanN, J. W., and SANFORD, J. P. (1970) f. infect. Dis., 122, 191

Mustakallio, K. K., Lassus, A., and Wager, O. (1967) Int. Arch. Allerg., 31, 417

Norins, L. C., Logan, L. C., and Lantz, M. A. (1970), f. Immunol., 105, 1108

Onisk, Z. (1965) Przegl. Derm., 52, 373

Peltier, A., and Christian, C. L. (1959) Arthr. and Rheum., 2,1

PinTo, L. (1960) Reumatismo, 12, 218

RITCHIE, R. (1967) Arthr. and Rheum., 10, 544

Singer, J. M., and Plotz, C. M. (1956) Amer. F. Med., 21, 888

- - Peralta, F. M., and Lyons, H. C. (1962) Ann. intern. Med., 56, 545

WILliams, R. C., and KUNKel, H. G. (1962) f. clin. Invest., 41, 666

Les réponses immunologiques humorales non spécifiques dans la syphilis latente et tertiaire SOMMAIRE

Les signes immunologiques humoraux non spécifiques furent étudiés dans le sérum de 53 malades atteints de syphilis latente ou symptômatique tardive et chez un groupe témoin de 180 sujets cliniquement sains, d'une même moyenne d'âge. Pour les sérums syphilitiques, les valeurs en protéïnes sériques totales, le profil des fractions protéïques à l'électrophorèse, les immunoglobulines $\mathrm{G}$ et $M$ furent augmentées à un degré hautement significatif. Pour les groupes SH, les différences ne furent pas significatives. Les auto-anticorps du type de ceux constatés dans la polyarthrite chronique évolutive et les anticorps antinucléaires ne furent pas constatés plus fréquemment dans les sérums syphilitiques que chez les témoins.

$\mathrm{Au}$ nom de ces constatations, on conclut que les modifications non spécifiques de l'immunité humoralelaissant penser à la persistance d'une stimulation antigénique-peuvent se rencontrer aussi bien dans la syphilis symptômatique tardive que dans la syphilis latente. Ces modifications semblent dues à une réponse immunologique aux antigènes de l'agent étiologique de la maladie plutôt qu'à un mécanisme d'auto-immunité déclenché par des déterminants antigéniques fraîchement développés dans des tissus lésés. 